ljtihad: Jurnal Wacana Hukum Islam dan Kemanusiaan

Vol. 18, No. 2 (2018), pp. 153-174, doi : 10.18326/ijtihad.v18i2.153-174

\title{
Sukuk model determinant as funding strategy of Islamic Bank in Indonesia
}

\author{
Muhamad Nafik Hadi Ryandono \\ Faculty of Economics and Business Airlangga University Surabaya \\ E-mail: muhammadnafik@feb.unair.ac.id \\ DOI : 10.18326/ijtihad.v18i2.153-174
}

The Sukuk issued by Islamic banks in Indonesia has high flexibility and is a unique strategy in funding but in its implementation still faces many determinants that need to be identified. This research uses a qualitative approach and the type of research is exploratory with case study method. The research finds seven determinants of sukuk as an alternative source of fundraising. In fact, these 7 determinants are obstacles to the issuance of sukuk, so that Islamic banks in the issuance of sukuk tend to choose to become Special Purpose Vehicle and or as a selling agent of sukuk. If it is related to a special project, the Islamic bank will develop public fund raising with mudharabah-muqayadah contract. The sukuk model that is suitable and sought by investors in Islamic banks is sukuk based on revenue sharing which is partnership contract. It is since partnership sukuk yield reflects business reality and economic cycle so that it is fair for the owner of fund and fund manager.

Sukuk yang diterbitkan oleh bank-bank syariah di Indonesia memiliki fleksibilitas yang tinggi dan merupakan strategi unik dalam pendanaan, tetapi dalam implementasinya masih menghadapi banyak faktor penentu yang perlu diidentifikasi. Penelitian ini menggunakan pendekatan kualitatif dan jenis penelitiannya adalah eksploratori dengan metode studi kasus. Penelitian ini menemukan tujuh faktor penentu sukuk sebagai sumber alternatif dalam penggalangan dana. Bahkan, ketujuh faktor penentu ini menjadi hambatan bagi penerbitan sukuk, sehingga bank syariah dalam penerbitan sukuk cenderung memilih untuk menjadi Special Purpose Vehicle dan atau sebagai agen penjualan sukuk. Jika terkait dengan proyek khusus, bank syariah akan mengembangkan dana publik dengan kontrak mudharabahmuqayadah. Model sukuk yang sesuai dan dicari oleh investor di bank syariah adalah sukuk berdasarkan pembagian hasil yang merupakan kontrak kemitraan. Karena hasil kemitraan sukuk mencerminkan realitas bisnis dan siklus ekonomi sehingga adil bagi pemilik dana dan pengelola dana.

Keywords: Determinant; Funding; Sukuk; Islamic Bank; Partnership 
ljtihad: Jurnal Wacana Hukum Islam dan Kemanusiaan, Volume 18, No. 2, Desember 2018: 153-174

\section{Introduction}

Islamic bank has two main functions namely as a business institution (tijarah) and as a social institution (tabbaru). As a business institution, Islamic banks are profit-oriented, while as social institution Islamic banks are oriented to social benefits in order to solely seek the pleasure and to worship of Allah. Islamic bank as a business institution (tijarah) runs five activities, namely intermediary, investment manager, investor, arranger and other banking financial services. In carrying out these five business functions, Islamic banks are supported by their own capital and funds sourced from the community. The fund is collected in the form of Third Party Funds (TPF). The development of TPF on Islamic Banking and Conventional Banking during the period 2007-2016 can be seen in Table 1.

Table 1. Deposit Development of Islamic Banks and Conventional Bank in Indonesia 2007-2016

\begin{tabular}{|c|c|c|c|c|c|c|c|}
\hline \multirow[b]{2}{*}{ Period } & \multicolumn{2}{|c|}{ Conventional Bank } & \multicolumn{2}{|c|}{ Islamic bank } & \multirow{2}{*}{$\begin{array}{c}\text { Total } \\
\text { Bank } \\
\text { (Rp. Billion) }\end{array}$} & \multirow{2}{*}{$\begin{array}{c}\text { Share of } \\
\text { Islamic } \\
\text { Bank to } \\
\text { Conventional } \\
\text { bank (\%) } \\
\end{array}$} & \multirow{2}{*}{$\begin{array}{c}\text { Share Bank } \\
\text { Syariah } \\
\text { Terhadap } \\
\text { Total bank } \\
(\%) \\
\end{array}$} \\
\hline & $\begin{array}{c}\text { TPF } \\
\text { (Rp. Billion) }\end{array}$ & $\begin{array}{c}\text { TPF } \\
\text { Growth } \\
(\%)\end{array}$ & $\begin{array}{c}\text { TPF } \\
\text { (Rp. Milyar) }\end{array}$ & $\begin{array}{c}\text { TPF } \\
\text { Growth } \\
(\%)\end{array}$ & & & \\
\hline 2007 & $1,990,3450$ & & 28,012 & & $2,018,357$ & 1.41 & 1.39 \\
\hline 2008 & $1,990,3450$ & 0,00 & 36,8530 & 31,56 & $2,027,198$ & 1.85 & 1.82 \\
\hline 2009 & $2,180,934$ & 9,58 & 52,271 & 41,84 & $2,233,205$ & 2.40 & 2.34 \\
\hline 2010 & $2,563,562$ & 17,54 & 76,036 & 45,46 & $2,639,598$ & 2.97 & 2.88 \\
\hline 2011 & $3,093,848$ & 20,69 & 115,415 & 51,79 & $3,209,263$ & 3.73 & 3.60 \\
\hline 2012 & $3,542,518$ & 14,50 & 147,512 & 27,81 & $3,690,030$ & 4.16 & 4.00 \\
\hline 2013 & $4,070,019$ & 14,89 & 183,534 & 24,42 & $4,253,5538$ & 4.51 & 4.31 \\
\hline 2014 & $4,594,876$ & 12,90 & 217,859 & 18,70 & $4,812,734$ & 4.74 & 4.53 \\
\hline 2015 & $4,909,708$ & 6,85 & 231,176 & 6,11 & $5,140,883$ & 4.71 & 4.50 \\
\hline 2016 & $5,399,210$ & 9,97 & 279,335 & 20,83 & $5,678,545$ & 5.17 & 4.92 \\
\hline
\end{tabular}

Based on Table 1, shows that deposits of Islamic banks in the period of 2007 to 2011 continue to increase both in number and share of conventional banking and total banking. In 2007 the share of Islamic banking to the total national banking only amounted to $1.39 \%$ and continues to increase to $3.6 \%$ in 2011 . This data gives meaning that during the period 
of 5 years the Islamic banks are able to penetrate the market well. But this condition in the next five years of 2012 to 2016 does not experience significant growth can even be categorized as stagnant. In 2012, the share of Islamic banks is only 4\% and in 2016 is still at $4.92 \%$ position so that for 5 years only increase $0.92 \%$ or average per year is only $0.18 \%$, this condition can be called as stagnant.

Stagnation on the funding side of Islamic Bank should not occur if Islamic banks can take advantage of its uniqueness in funding, because if it relies on intermediary institutions it will be difficult to compete with conventional banks that have been very experienced as financial intermediary institutions. Islamic banks should utilize its function other than intermediation that does not exist in conventional banks. Such uniqueness is the function of investment managers, investors and investment arranger. These three functions can be done by issuing Islamic business-based securities to be financed, which in the Islamic Financial System is better known as sukuk.

Sukuk in Islamic banks has been less popular in the Islamic banking industry. This happens because in the issuance of sukuk, the management of Bank Islam only acts as an agent so that it only gets tangible fee (ujrah) income only and the income of ujrah is not as big as income as an intermediary institution. This condition can be different if Islamic Bank in the issuance of sukuk acts as investment manager, investor and investment arranger. In these three functions Islamic banks can obtain fixed returns and / or variables according to the revenues of the projects it finances.

Although the Sukuk issued by Islamic banks has high flexibility and is a unique strategy in funding but in its implementation still faces many determinants that need to be identified and looked for solution. The search for a sukuk determinant solution as an Islamic banking funding strategy requires in-depth study and research both qualitatively and quantitatively. Based on the above description, this research conducts research on; Determinants of Sukuk as a Funding Strategy at Islamic Banks. The formulation of the problem is; What is the determinant of issuance of sukuk as a funding strategy for Islamic banks in Indonesia?

Islamic Bank is a business institution (tijarah) as well as a social institution. The function of Islamic Banks became clearer after the issuance of Law No. 21 of 2008 on Islamic banking, as in Article 4 which mentions Islamic banks other than as an intermediary 
ljtihad: Jurnal Wacana Hukum Islam dan Kemanusiaan, Volume 18, No. 2, Desember 2018: 153-174

institution (collecting and channeling public funds) can also perform social functions in the form of baitul maal institutions. Islamic Bank as baitul maal then Islamic Bank may collect and distribute Zakat, Infaq, and Shadhaqah (ZIS) and as manager of waqaf (endowment) and may use ZIS as source of loan fund for good (qardul hasan).

Islamic banks in business must balance the benefits of the world and the hereafter. The objective substance of the shariah (Islamic jurisprudence) is that human life becomes easy and prosperous in the world and the hereafter. This is in line with the opinion of Imam Ghazali and Ibn Qayyim. Ghazali argues that, "The ultimate goal of the shari'ah is to preserve human welfare that includes the protection of their faith, social life, minds, descendants, and possessions. Whatever guarantees the protection of these five matters is human and desirable. "While Ibn Qayyim, argued; "The base of the Shari'ah is the wisdom and the benefit of man in the world and the Hereafter. This welfare lies in perfect justice, mercy, prosperity, and wisdom. Anything that makes justice an act of persecution, grace becomes violence, ease becomes a difficulty, and wisdom becomes ignorance, then it has nothing to do with shariah" (Ghazali : 2009). The basic objective of Islamic banking Syahdeini (1999: 21) is "to provide financial facilities by seeking financial instruments in accordance with sharia provisions and norms." Islamic banking is not intended primarily to maximize profits as well as an interest-based banking system but to provide socio-economic benefits to Muslims." This opinion is in line with Chapra's (1985) opinion:" Islamic commercial banks are different from conventional banks in two respects, namely the elimination of usury and the derived from society should be used to serve the public good and not the individual interests."

Lewis and Algaoud (2007: 123) argue that; "The main objective of Islamic banking and finance is the elimination of usury from all financial transactions and renewal of all bank activities to conform to Islamic principles, reasonable distribution of income and wealth, and economic development progress". Mannan (1970: 203) states that; “The general function of sharia-compliant banks is to provide ordinary general banking services, provide non-open investment accounts, provide facilities to attract funds for investment in trade and business, and ultimately provide humanitarian social services, allowing interest-free withdrawal and special virtue payments (qardul hasan). Islamic Bank on its substance is to achieve the goal of Islamic syaiah because every activity undertaken by Islamic banks is a manifestation of 
the practice of Islamic sharia.

Islamic Bank funding comes from internal and external sources. The external fund consists of Third Party Funds (TPF), namely the deposit funds (wadiah yad dhamanah contract) and investment funds (mudharabah mutlaqah contract), sukuk and funds with ijarah agreement. The second source is the internal funds of the paid up capital by the owner and the current profit that has not been paid as dividends. The funds are then made into one (pooling fund) which will then be disbursed as financing. Then financing in Islamic banks generally uses four main principles of profit sharing (mudharabah and musharaka), sale and purchase (murabahah, istishna, and salam), rent (jarah) and soscial (qard and qardul hasan). Revenue gained from the financing of the profit-sharing principle is the revenue sharing from the fund management by the financing customer. This profit sharing ratio is determined when the contract is agreed upon and the payment is based on the results it earns, so the revenue-sharing income is not the same in each period. The operational system of Bank Islam as a business institution and social institution can be seen in Figure 1. 
Figure 1. Islamic Bank Operational System

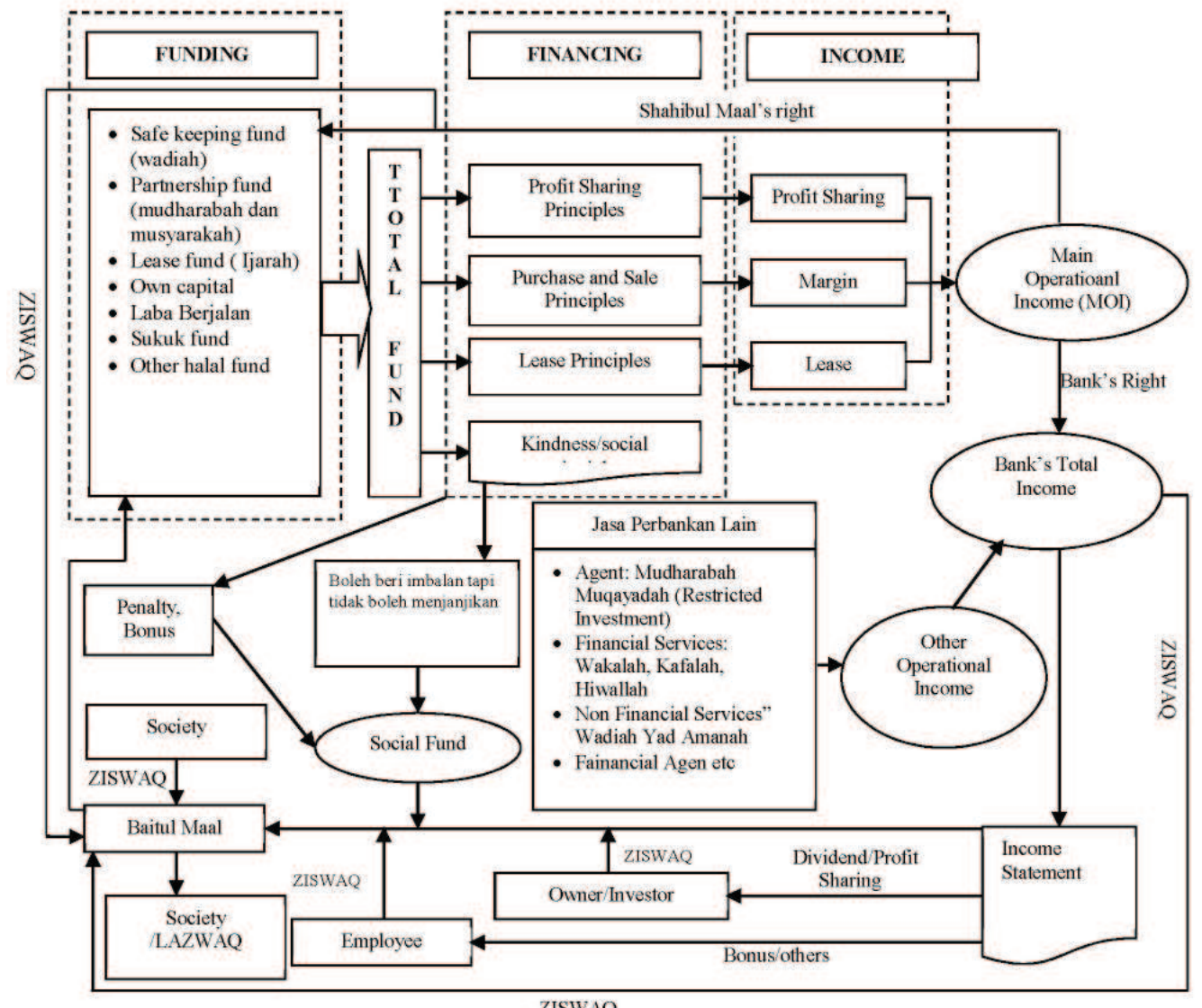

Financing revenue by the principle of sale and purchase is the agreed profit margin at the time the contract occurs. Revenue from this sale and purchase contract is fixed in every period. Revenue from the financing of the lease principle is the rental fee agreed upon at the time of the contract, and fixed in each period. Financing with the principle of goodness (tabbaru) because the intention is good that only expect return from Allah alone is not allowed the promised income in time, the amount of rupiah and the percentage. But in this honorable contract the beneficiary may give reward as a token of gratitude but should not be promised at the time of contract, because if agreed is included usury. Income received by the bank from this good deed may not be included in the bank's operating income but 
shall be included in the social funds account. The social funds account is also sourced from penalties and other bonuses received by the bank.

Revenue-sharing revenue, margins and rents are collected into Main Operating Income (MOI) of Islamic banks. The MOI will be divided between the bank and the owner of the Third Party Fund (TPF) based on the agreed profit sharing ratio. If the bank will provide a bonus to the wadiah contract customer then the bonus must be taken from the portion of the rights to wadiah funds and should not be taken from the management of funds outside the wadiah funds.

The Islamic Bank, in addition to obtaining revenue from fund managers, generally has a source of other Operating Income (OOI) in the form of Fee Based Income (FBI) sourced from bank services such as fee as agent of mudharabah muqayadah (investment tied), fee from financial services on akad wakalah, kafalah, hiwallah and non-financial services on wadiah yad amanah contract. Rights of MOI and FBI are aggregated into one into Total Operating Revenue (TOR). TOR after deducting with operating expenses and other expenses when reaching nisab then must be issued zakatnya and input in account baitul maal and pay taxes. The rest may then be partially distributed to all the Human Resources (SDI) within the bank and give the owner as dividends and profit sharing to the existing investor according to the agreement that has been made.

The employees of the bonus recipient, the recipient of the dividend and the profit-sharing investor if they reach Nisab will then adjust Zakat, Infaq, Shadaqah and Waqaf (ZISWAQ) through the Islamic bank so that all ZISWAQ receipts will enter the baitul maal account. Besides ZISWAQ from outside banks (the public) that compiled to Islamic banks.

Sukuk is derived from Arabic; صكوك, which is the plural of صك or «sakk», otherwise known as «legal instrument, deed, check»). Sukuk in terms are defined as securities containing financing contracts based on sharis principles. Initially the sukuk was equated with syarisah bonds, which according to the DSN No: 32 / DSN-MUI / IX / 2002 Fatwa, defines Islamic bonds: "A long-term securities based on Shariah principles issued to issuers of Islamic Bonds which requires Issuers to pay revenues to holders of Islamic Bonds in the form of profit sharing or margin or fee as well as repay fund of Islamic bonds at maturity ". 
ljtihad: Jurnal Wacana Hukum Islam dan Kemanusiaan, Volume 18, No. 2, Desember 2018: 153-174

Islamic bonds and conventional bonds are very different. Islamic bonds return system is profit sharing system, margin and fee while conventional bonds return system is the interest system. Interest is one embodiment of usury so that conventional bonds are haram for possession and trading. Therefore, the term "Islamic Bonds" is not to be debated, although the term is wrong but substantially does not violate the rules of figh. But in the future the use of the term Islamic bonds should be avoided, since bonds mean these instruments are debt instruments. Islam prohibits the sale of debt, so that this instrument should not be traded on the syariah capital market. The term Islamic bond was then used because the issuer based the law on bonds, but after the issuance of the Law of the Republic of Indonesia Number 19 Year 2008 on the State Islamic Securities, the term Islamic bonds is not known anymore but more familiar with the sukuk.

Islamic bank if will issue sukuk then the contract that can be used and selected should be adjusted with the business model to be financed. After the sukuk agreement is selected, the islamic bank can then create a sukuk structure to facilitate in determining the rights and obligations of each party involved in the sukuk transaction. The process of establishing a relationship pattern between related parties and the flow model as well as the transaction agreement used in the sukuk contract is called the process of sukuk structure. In general, the issuance of sukuk is as in Figure 2. 


\section{Figure 2. General Proses of Sukuk Issuance}

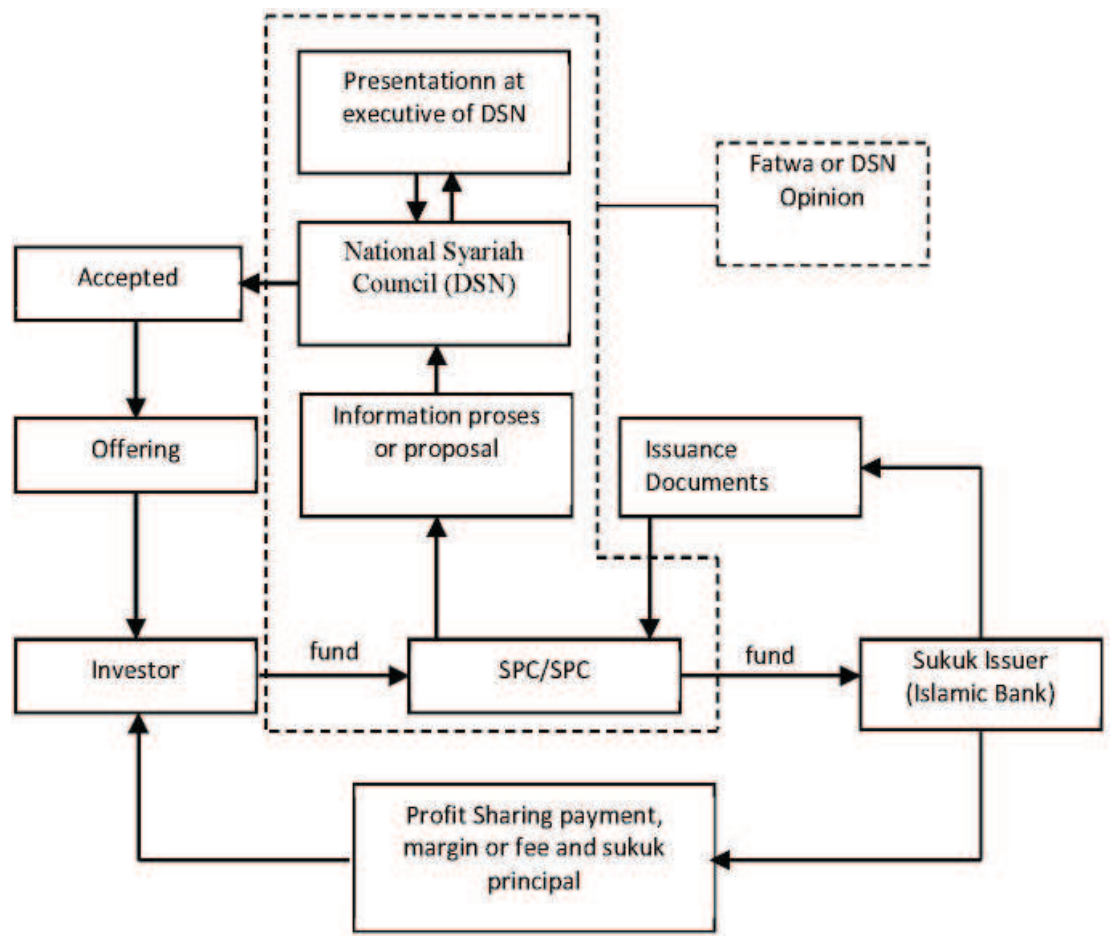

At the time of issuing sukuk, internal preparation and preparation of documentation as required to go public or public offer are required, and to comply with all requirements stipulated by the sukuk publishing authority. The process of sukuk issuance, in general is not much different from the conventional bond issuance process. The substantial difference is the existence of a fatwa or opinion process from the National Shari'ah Council (DSN) of the Indonesian Ulema Council (MUI) and the Sharia Supervisory Board (DPS) in the issuance of sukuk while the conventional bond issuance is absent. Issuance of sukuk requires three main stages: preparation phase of sukuk issuance, process in Financial Services Authority (OJK), public offering and recording and trading process.

The previous researchs related to this study are: Bulutoding and Umar (2016) in Kaffah Studies Thinking about Sukuk Products in Increasing Funding at PT Bank Sulselbar Syariah Makassar proved that sukuk is can be used to create funding of PT Bank SulSelBar Syariah Makassar. According to the SulSelBar Syariah treasury bank department, the use of sukuk 
is the right decision. The decision to choose sukuk funding alternatives is not just because a demand of sharia based in financial institutions, but also because sukuk are proven in the economy can be a connecting point for conventional and sharia companies. Through sukuk, it is expected to be an alternative that can maintain the stability of a prolonged funding structure. In addition, Bulutoding and Umar (2016) stated that sukuk is an intermediation between companies and investors in introduce companies in the secondary market, a new hope to improve the corporate image of the Bank Syariah in a wider scope, namely national scope.

Khairunnisa (2012) in her research The Impact of Sukuk on Corporate Financing: Malaysia Evidence, discussed the role of sukuk in the structure of capital targets in companies and countries. In the findings of the study it was found that sukuk proved to have a significant influence on the structural variations of the company's capital in Malaysia and to the country. Khairunnisa (2012) also added that the use of sukuk can create business opportunities for its publishers.

Ryandono (2018) in a previous study entitled Sukuk as an Economic Solution Alternative for Financing Infrastructure development in Indonesia explained the integration of waqf and sukuk as an alternative to infrastructure development. Waqaf and sukuk in their implementation can be combined, namely waqaf can be a source of sukuk funds. If the waqaf funds are invested in sukuk, the Nadzir will receive the proceeds from the infrastructure income. The acceptance of the waqaf utilization's results will be distributed to the beneficiaries of waqaf (maukuf alaih). The beneficiary may also be the government so that it becomes revenue to the APBN. APBN revenue from waqaf can be used to take over or repay the principal sukuk infrastructure and or build other infrastructure so that the wheels of the economy will spin optimally.

\section{Method of research}

This research uses a qualitative approach and the type of research is exploratory with its strategy (method) is a case study. The case study strategy is chosen because it allows for indepth research results and is difficult to manipulate because researchers have little chance of controlling events to occur. The selected case study is a case study developed by Robert Yin. Yin (2000: 18) argues that, "empirical inquiry that investigates phenomena in the real- 
life context when the boundaries between phenomena and context do not appear firmly and where multiple sources are utilized."

The exploratory case study method is chosen by argument; First, case study strategies allow research results to be difficult to manipulate. Second, is a strategy that matches the research question in this research is "how". Third, the focus of research lies in the phenomenon of issuance of sukuk by syariah banking as a funding strategy so that the required data is not only historical data but required interviews, discussions and direct observation. Fourth, the research is done in fact syraiah bank has not used much sukuk as an instrument in funding (funding). Fifth, this study is a study for; 1). knowing, analyzing and mapping out the determinants in the issuance of sukuk in syariah bank in Indonesia). 2). Finding a sukuk model that is compatible with islamic banking system in Indonesia. To achieve these two goals requires a proposition for the research to be a determined focus. His research proposal is sukuk is a unique funding strategy for islamic banks so that if optimized will increase funding and is the way out of funding stagnation.

The focus of this research is the determinant of issuance of sukuk in syariah bank as a strategy in funding in order to find sukuk model in accordance with syariah banking system in Indonesia. Thus factors and events events outside the context will be ignored or if used only as a note only to strengthen the argument at the time of discussion of research results. If there are findings that are interesting and dominant in field observations and that is a refinement in answering research questions will be included in the discussion as research findings. The main data is the results of interviews to informants, namely islamic banking, academics and Islamic jurisprudence experts and Islamic banking. The analysis technique chosen is narrative analysis. This technique is chosen because the results of observations and interviews can be dinaratifkan flow according to the findings in the field then made the synthesis and analysis for easy in making conclusions.

\section{Sukuk as a fundraising strategy for Islamic bank}

Sukuk as a fundraising strategy for Islamic banks based on exploration and qualitatively can be classified into 7 determinants, namely (1) Human Resources, (2) Positive Law, (3) Financial Fiqh, (4) Transparency of Islamic bank business and project from sukuk, (5) Management 
ljtihad: Jurnal Wacana Hukum Islam dan Kemanusiaan, Volume 18, No. 2, Desember 2018: 153-174

Readiness, (6) Competition of Financial Instrument Market, and (7) investment object of sukuk. Human Resources, consisting of competent Human Resources (SDI), trustee, and Sharia Supervisory Board (DPS) Positive law, which includes long-term licensing, islamic banking financing policy from the banking authority, any sukuk issuance must be approved by the Banking Authority, taxation, the provision of the issuance fee, the requirement of a sukuk trustee, the fulfillment of the involvement of the parties in the issuance of sukuk and sukuk must be assessed. Fiqh among others; Inequality of fiqh and business expertise between DPS member and Islamic bank management, acquisition and management of sharia lawsuit with proven fatwa from National Sharia Council (DSN), every sukuk contract must receive a DSN fatwa, and figh provision that the paid yield must be sourced from project financed.

Transparency is the business information of islamic bank and the project of sukuk and distortion of information because of moral hazard. Management ie; management capability in providing prospective returns, relatively large sukuk issuance costs, the role of DPS that has not been maximized, issuance of the old sukuk is considered inefficient, the administration is many and complicated and the parties prefer the yield of profit sharing system in the issuance of sukuk.

Market Competition Financial Instruments, among others, the non-preparation of syariah bank syukah compete with corporate and state sukuk and other conventional syariah securities and Islamic instruments, cannibalism to other Islamic bank funding products, large market potential, the demand for yields competes with conventional finance instruments, yield certainty, abhwa market image of sharia products more complicated and expensive, the market is familiar with sukuk, shariah compliance demands, and education and socialization that has not been massive. The object of sukuk investment is that of the project owner when the risk of small business and the prospect prefer the return but when the big risk business demands the yield variable, the project owner is less familiar with the sukuk, is not ready for transparency, moral hazard, the reluctance of additional guarantees in addition to the projects financed.

There is no fixed recipe for presenting the findings of a study. We will, therefore, first consider general guidelines and then turn our attention to options for reporting descriptive statistics and the results of hypothesis test. The seven determinants mentioned above are 
assessed by the islamic bank is an advantage and also inhibiting sukuk as an alternative fund raising. But from the results of exploration in the field more rate as an obstacle so that sukuk less interest by Islamic banks as an alternative fund raising. Although the actors of islamic banks in this case the management considers that the sukuk is a funding source that potential and more appropriate with large projects such as infrastructure financing.

The main determinants of sukuk publishing are the availability and competence of Human Resources (SDI), information disclosure and sukuk issuance costs, financial market instrument competition and internal bank information disclosure requirements, taxation, fee rules and issuing procedures, and management of islamic bank. The reality of this determinant is still a barrier to the issuance of sukuk so that Islamic banks in the issuance of sukuk tend to choose Special Purpose Vehicle (SPV), sales agents, investors and investment managers of sukuk issued by other parties. If it is related to a special project, islamic banks are more likely to develop public funding using mudharabah muqayadah contract. Why tends to choose mudharabah muqayadah or better known as bonded investment term, because for the bank for this product the risk is small and the bank gets a fee arranger whose value is fixed based on the size of the managed funds. On this contract at the time of the project the loss of the bank does not participate bear the risk of losses due to business and financial risks borne by investors and project owners.

Based on the results of field observations obtained sukuk in accordance with the operations of Islamic banks is sukuk-based profit sharing. This revenue-sharing dividend is more in demand by investors or investors because investors believe that the projects handled by the bank have been through good and accurate selection so that investors will share the risk and returns that match the revenues of the sukuk-funded project. Sukuk for the results of interest are sukuk with akad ravish and musharaka. At the issuance of this sukuk, the party may act as a trustee, Special Purpose Vehicle (SPV) in this case Islamic banks, sales agents, investors, and investment managers.

\section{Sukuk Mudharabah}

Mudharabah sukuk is practically a cooperative effort between two or more parties where one party (shohibul maal) finances 100\% and the other party (mudharib) with expertise 
ljtihad: Jurnal Wacana Hukum Islam dan Kemanusiaan, Volume 18, No. 2, Desember 2018: 153-174

and profesionalmanya will manage the fund and the results obtained will be divided based on nisabah agreed upon on the contract crew. Mudharabah agreement with more than one person through one transaction. That means he can offer his money to A and B so that they become mudharib. Mudharabah and mudharib sectors must be managed and provided by $\mathrm{A}$ and $\mathrm{B}$ together.

The practice of mudharabah contract in sukuk is the issuance of securities containing financing contracts using mudharabah contract system. Mudharabah sukuk may also be defined: "as a securities containing financing contracts based on shariah principles issued by companies (issuers), governments or other institutions requiring issuers to pay income to sukuk holders in the form of profit sharing from the results of management funds that have been deposited by the owner of the funds and repaid the principal of sukuk at maturity ".

For the sake of mudaraba validity, all parties must agree on the proportion of actual profit to be received by each party. There is no particular proportion established by the Shariah, but submitted a consensus together. They can share profits in equal proportions, or they can also set different proportions for Rab al-Mal and Mudharib.

Mudharib and Rab al-Mal shall not allocate lump sum amount to any party or determine any part of the party at a certain level based on capital. However, they may approve 40\% of actual profit for mudarib and 60\% for Rab al-Mal or vice versa. For example, Rab al-Mal may declare to mudharib: "If you trade wheat, you will get $50 \%$ of the profits, but if you trade in flour, you will get $33 \%$ of the profits".

In addition to the agreed proportion of profits, mudarib can not claim a periodic salary or commission or remuneration for the work it does in mudaraba. All Islamic Fiqh experts agree on this matter. However, Imam Ahmad has allowed mudharib to claim daily expenses to eat from mudaraba accounts. Hanafi lawyers limit the mudharib’s right to claim personal expenses, accommodation, meals, etc. only in situations where he is on a business trip out of town. If the company suffers a loss on some transactions and benefits from some other transactions, then first the profits will be used to cover the losses, then if any of the remaining shares are distributed to the partners according to the agreed ratio.

Mudharabah becomes invalid (Fasid) if the profits remain in a certain way. If this happens, then all will belong to Rab al-Mal. Mudharib will only be an employee obtaining Ujrat-e-Misl. 
The remaining amount is called profit and will be divided according to the agreed ratio.

The mudharabah sukuk contract is defined as a contract of cooperation between two or more parties in which there are parties as a funder (shohib al-maal) or one hundred percent investor while the other party (syariah bank) as a party possessing skill and professional in business or entrepreneur (mudhorib). The results of the business will be shared together according to the ratio agreed upon in the contract. Shohibul maal party will bear the financial risk, meaning that if sukuk not get profit then the investor will not get return of investment. While the entrepreneur will bear the business risk, the intention if the business does not get profit then the issuers who have worked do not get rewarded from the work caused by the cycle economic and business cycles that occur. But if the risks and losses that occur due to negligence or deliberate mudhorib then will be the responsibility mudhorib. If the negligence and intent of the issuer resulted in unpaid sukuk principal at maturity then at that time the user of the funds owed the investors to the islamic bank to the investor.

The parties involved in sukuk mudharabah are investors (sukuk holder or shahibul maal), Special Purpose Vehicle (SPV) in the case of syariah and corporate bank (mudharib). Investors invest in mudharabah sukuk through islamic banks on the basis of consideration are the prospectus issued by the company and other relevant information.

For investors mudharabah sukuk means they have become shahibul maal for islamic banks whose composition is equal to the ratio of the total value of t sukuknya divided by the total funds required in the sukuk mudharabah. This composition is also a share of the share of the management of the mudharabah sukuk funds.

The revenue-sharing revenue will be received periodically by the syariah bank from the project owner in accordance with its ratio, then the syariah bank will distribute it periodically to the sukuk mudharabah investors in accordance with the respective ownership composition of the sukuk. The principal of sukuk will be paid back at maturity of the investment value of each investor. The mudaraba sukuk model can be seen in Figure 3. 
Figure 3. Mudharabah Sukuk Model at Islamic Bank

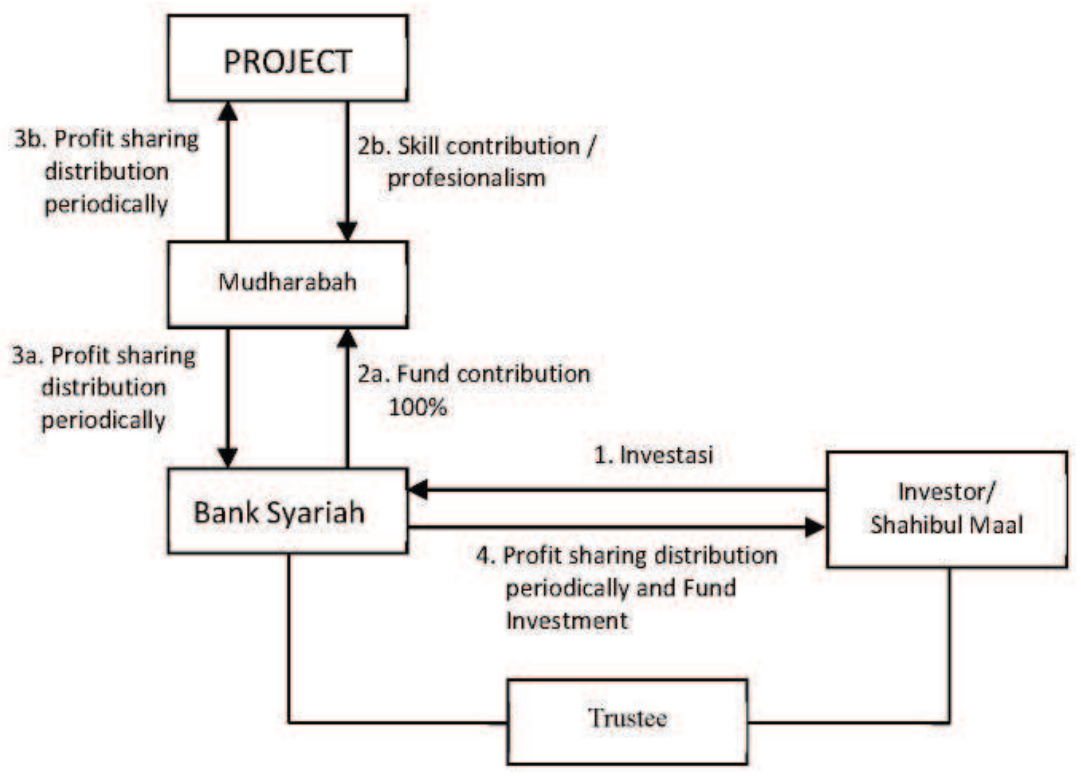

\section{Sukuk Musharakah}

Musharaka or shirkat-ul-amwal is a relationship established by some parties through mutual contracts. Therefore all components required for legitimate contracts must be available. There are also certain components specific to musharaka contracts. The proportion of the profits distributed to the partners must be approved from the date of entry into force of the contract. If no proportion is established, then this contract is deemed invalid according to the Shariah.

The profit ratio for each partner should be determined as a proportion to the actual profit the firm accrues, not the proportion to the capital it invests. In musharaka it is not justified to establish lump sum amount for any partner, or set profit rate in the form of proportion to the capital invested.

For example if A and B join a partnership and agree that A will receive Rp 10,000 per month as part of the profits, and the remainder is given to $\mathrm{B}$, then this partnership is considered invalid. Similarly, if it is agreed that A will get $15 \%$ of its investment, then this contract is also considered invalid. The correct division base is an approved percentage of 
the actual profits earned by the company. If a lump sum amount or a certain percentage of the capital has been approved for one party, it should be clearly stated in the agreement that it will be subject to final settlement at the end of the period. Thus, whatever money received by each partner is considered an 'on account payment' and will be adjusted to the actual profit earned at the end of the period. If there is no profit generated or less than expected, then the amount received by the partner must be returned.

Islamic jurists have different opinions about whether or not the profit ratio of each partner is adjusted to the ratio of capital invested. According to Imam Malik and Imam Shafi, for musharaka to be legitimate, each partner must profit by the same proportion as the proportion of invested capital. Meanwhile, according to Imam Ahmad, the profit ratio may differ from the investment ratio as long as all parties agree. Another view was put forward by Imam Abu Hanifa. According to him, under normal conditions, the profit ratio may differ from the investment ratio. But if a partner states in a preliminary agreement that he will not work for musharaka, then his share of profits should be no more than the investment ratio.

Islamic jurists agree that in the event of loss each partner must bear losses according to his investment ratio. Therefore, if a partner invests $40 \%$ of capital, he / she should bear $40 \%$ loss. According to Imam Shafii, the ratio of profit and loss of a partner must be in accordance with the investment ratio. According to Imam Abu Hanifa and Imam Ahmad, the loss must be shared with the proportion equal to the capital ratio invested by each partner. This principle is often referred to as: "Profits are divided according to the agreement of all parties, but losses always depend on the investment ratio". The Mosukakah Sukuk model can be seen in Figure 4. 
Figure 4. Musharakah Sukuk Model at Islamic Bank

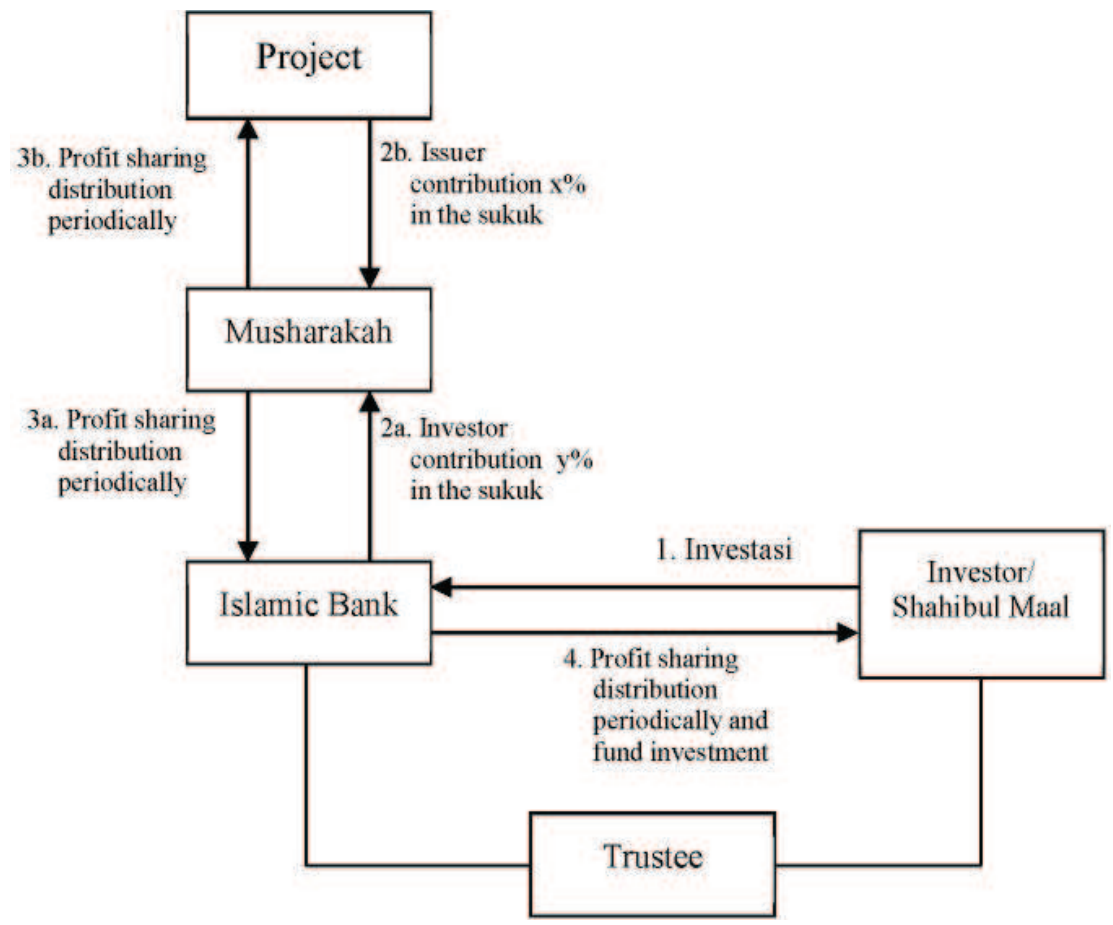

The general principle musharakah is that all partners have the right to take part in the management of the company. However, under certain conditions the partners may agree to hand over management affairs to one of them only. In such cases, a sleeping partner will benefit from the investment alone, and the profit ratio it earns should not exceed the investment ratio.

If all partners agree to work in a joint venture, then each must act as another partner agent in all business matters. All the work done by each partner in a common business activity is considered to be authorized by all other partners. Revenue-sharing income will be received periodically by syariah bank, then will also share it periodically to the sukuk investors according to their ownership composition (inclusion). The principal of sukuk will be paid back at maturity of the investment value of each investor.

Mudharabah Muqayyadah as the Uniqueness of Islamic Bank Fundraising Model in Special Project 
Mudharabah muqayadah can be developed and operated independently by every syariah bank but also can form consortium between syariah bank especially for project which need big fund which can not be borne by one bank only. Mudharabah muqayadah fund collection by one syariah bank only. In this mudharabah muqayadah contract the parties are bound by the provisions that have been determined by the owner of the fund or investor (shahibul maal). Model or structure akadnya can be seen in Figure 5.

\section{Figure 5. Mudharabah-Muqayadah Sukuk Model}

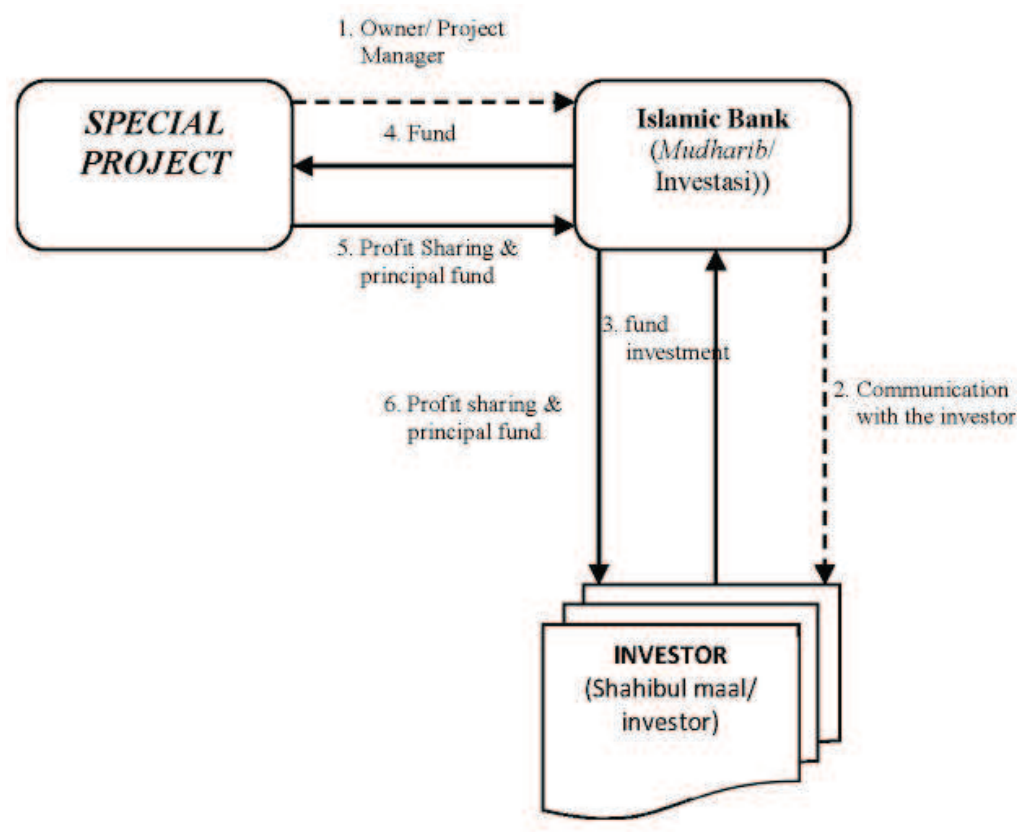

In this special project or special investment the Islamic bank can act as a funding as well as financing so that it fits in the difficult conditions of finding project funding because it may be a crisis where losses occur thoroughly in the economy. Why is that? Because investors can invest funds into projects that have been selected by the banks and do not need to manage their own investment but managed by the investment manager of islamic bank. On the other hand the certainty of costs and yields that prospects because it has been selected specifically by the Islamic bank more controlled project financed it. On this card the islamic 
ljtihad: Jurnal Wacana Hukum Islam dan Kemanusiaan, Volume 18, No. 2, Desember 2018: 153-174

banks do not bear the risk of the project because it acts as arrangger and investment manager only so that if there is a risk that bear is the owner of the special project and the investors with mudharabah muqayadah agreement. The mudharabah muqayadah model which is a consortium of several Islamic banks can be seen in Figure 6.

Figure 6. Mudharabah-Muqayadah Sukuk Consortium Model

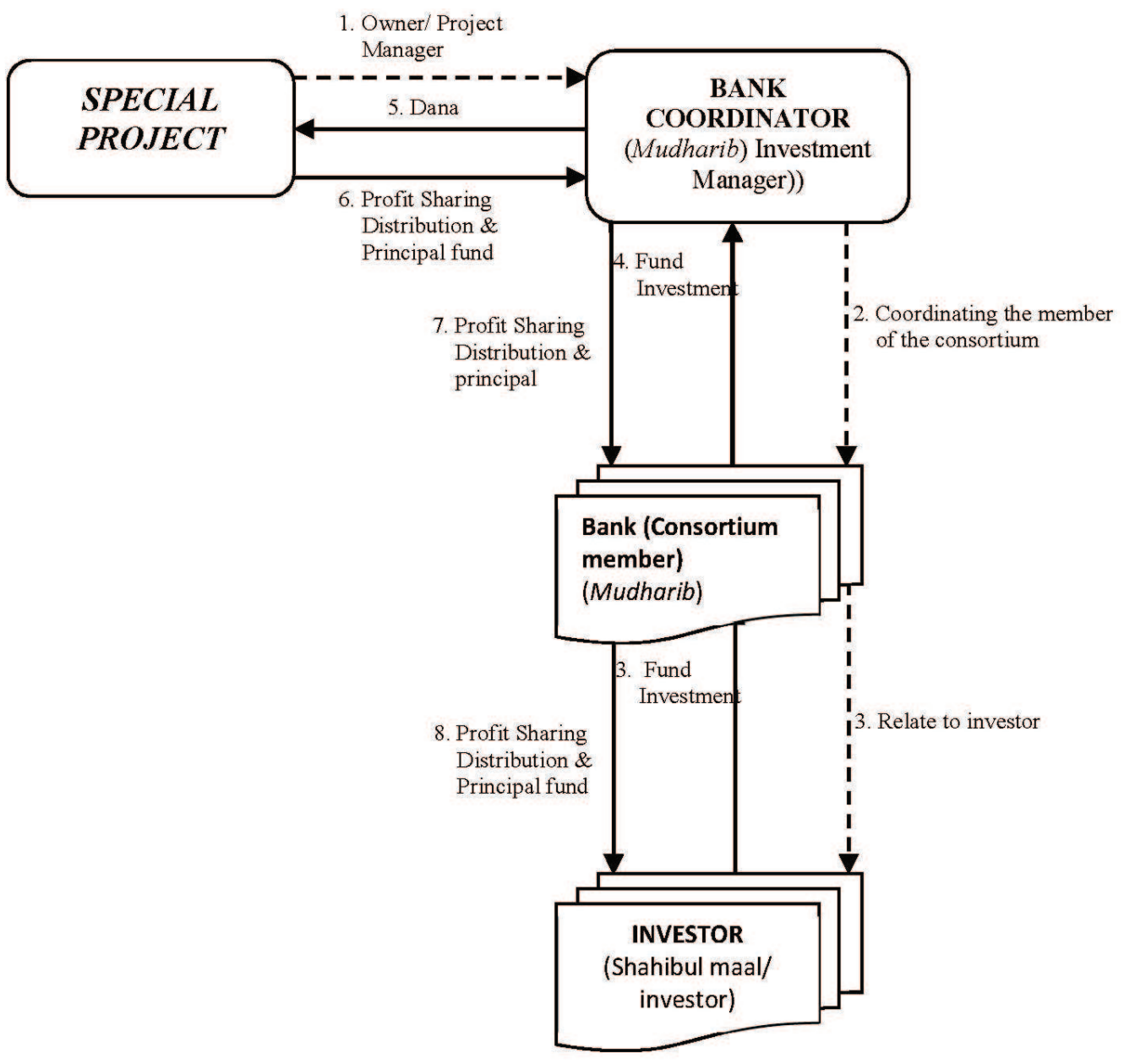


Sukuk model determinant as funding strategy of Islamic Bank... (Muhamad Nafik Hadi Ryandono)

\section{Conclusion}

Determinants of sukuk as an alternative source of fundraising on sharia is determined 7 determinants are (1) Human Resources, (2) Positive Law, (3) Financial Fiqh, (4) Transparency of syariah bank business and project of sukuk, (5) Management Readiness , (6) Competition of Financial Instrument Market, and (7) investment object of sukuk.

The result of observation states that the sukuk which is in accordance with the operational of Islamic bank is a sukuk based on profit sharing, namely sukuk with syirkah contract (parthership) ie contract of mudharabah and musyarakah. At the issuance of this sukuk various parties can act as trustee, Special Purpose Vehicle (SPV) in this case Islamic banks, investors, investment managers, and sales agents. This sukuk is more in demand by the owner of the fund or investor. This is because investors believe that the projects handled by the bank have been through a good and accurate selection so that the investors are willing to share the risk and returns in accordance with the revenue of the sukuk-funded project.

Sukuk using syirkah contract is sukuk mudharabah and sukuk musyarakah. The argument from the selection of the sukuk pertnership is that the yield of the sukuk partnership reflects the actual business condition so that it is the right for the owner of the fund (shahibul maal) and the fund manager (mudharib).

Seven determinants are still a barrier to the issuance of sukuk so that Islamic banks in the issuance of sukuk tend to choose Special Purpose Vehicle (SPV), sales agents, investors, and investment managers. When it comes to the special project strategy taken by islamic banks is to develop public fundraising by using mudharabah muqayadah contract.

\section{Bibliography}

Bulutoding, Lince dan Umar, Islailia. Kajian Kaffah Thinking Produk Sukuk dalam Meningkatkan Pendanaan pada PT Bank Sulselbar Syariah Makassar. Jurnal Assets, Volume 6, Nomor 2, Desember 2016: 221-232

Ghazali, Imam. Ringkasan Ibya’ Ulumuddin. Cetakan I, edisi revisi, Jakarta: Pustaka Amani, 1995.

Ibya' 'ulumuddin. Jilid I, translation by Purwanto, first edition, Surabaya: Marja, 2009. Holy Al Qur'an 6.5 \& Al Hadist 30 Juz Versi Indonesia. 
ljtihad: Jurnal Wacana Hukum Islam dan Kemanusiaan, Volume 18, No. 2, Desember 2018: 153-174

Ibrahim, Wirman, et al. Alternative Disclosure and Performance Measures for Islamic Banks. Malaysia: International Islamic University, 2003.

Khairunisa, I dan Razali. H. The Impact of Sukuk on Corporate Financing: Malaysia Evidence. Journal of Islamic Finance, 1(1): 001-011. 2012

Lewis, Mervyn K\&Latifa M. Algaoud. Perbankan Syari'ah :Prinsip, Praktek dan Prospek. Translation by Burhan Subrata, Jakarta: PT Serambi Ilmu Semesta, 2007.

Mannan, M. A. Islamic Economics, Theory and Practic. Leicester, United Kingdom: The Islamic Foundation, 1970.

Ryandono, Muhamad Nafik Hadi. Sistem Operasional Bank Islam dan BMT. Modul Pelatihan Dasar-Dasar Perbankan dan BMT. Surabaya: IFDI 2008 Peran Dan Pengaruh Penghimpunan Dana Dan Penyaluran Dana Serta Kinerja Bank Terhadap Kesejahteraan Karyawan Bank Islam Perspektif Maqashid Syariah Di Indonesia. Surabaya: Disertasi pascasarjana Unair, tidak dipublikasikan, 2010

Sukuk sebagai Alternatif Solusi Ekonomis Pembiayaan pembangunan Infrastruktur di Indonesia. Universitas Mulawarman: Simposium III UNIID,2018

Syahdeini, Sutan Remy. Perbankan Islam dan Kedudukannya dalam Tata Hukum Perbankan Indonesia. Jakarta: Grafiti, 1999.

Undang-undang. No. 21. Tahun 2008. Undang-Undang Perbankan Syariah.

Yin, Robert K. "Case study evaluations: A Decade of Progress?" Evaluation models. Springer, Dordrecht, 2000. 185-193. 